\title{
HUBUNGAN SIMBIOTIK MANUSIA DENGAN LINGKUNGAN DALAM ISLAM
}

\author{
Nawawi*
}

Abstrak: This paper states that Islam is a comprehensive religion that not only regulates the problem of worship but covers all aspects of life and is not only related to thirst but also relates to spirituality. Islam has two important meanings for humans as a basic concept for life, namely the meaning of what religion does (the function of religion in life) and the meaning of wahat is religion (the meaning of religion for life). Both of these meanings are closely related to buman relations with the environment, where the relationship of both are equal or symbiotic, namely mutual benefit between humans and the environment. As a form of implementation of rabmatal lil 'alamin, human relations with the environment consists of three principles. First, the principle of respect for nature. Second, the principle of environmental responsibility. Third, the principle of caring for the environment. These three principles will not be effective, so it requires control from the authorities, namely severe punishment to the death penalty. Without severe punishment, the environment will become extinct because it is exploited by bumans arbitrarily.

Keywords: Symbiotic, Human, Environment, Islam

* Penulis adalah Dosen tetap IAI Ibrahimy, Komp. Masjid Ibrahimy No. 1-2 Situbondo, No. Hp.085330867176, email: nawawithabrani71@gmail.com 


\section{PENDAHULUAN}

Masalah lingkungan hidup dewasa ini telah menjadi isu global karena berkaitan dengan berbagai sektor dan kepentingan manusia.Kerusakan lingkunganyang terjadi saat ini dapat dikatakan telah menyebar di berbagai belahan dunia, terutama Indonesia. Dengan potensi alam Indonesia yang melimpah telah membuat orang-orang berusaha untuk mengolah secara maksimal. Bahkan potensi alam dapat menarik investor-investor asing untuk berbisnis di negeri ini. Dari aspek potensi alam dapatmemajukan perekonomian negara, tetapi di sisi lain justru dapat membuat orang untuk mengeksploitasinya dengan sewenang-wewang. Akibatnya, banyak pengusaha yang semakin berambisi mengelolahlingkungan di negeri ini tanpa mempertimbangkan kemaslahatan umum.

Penelitian tentang 'Ekonomi Politik Kebakaran Hutan dan Lahan' dari peneliti Center for International Forestry Research (CIFOR) Herry Purnomo. Kerumitan di lapangan, menurut Herry, terjadi karena para pelaku pembakar hutan, baik masyarakat maupun kelas-kelas menengah dan perusahaan selalu berhubungan dengan orang-orang kuat, baik di tingkat kabupaten, nasional, hingga tingkat ASEAN. Masing-masing kelompok yang melakukan pembukaan lahanbaru akan mendapat persentase pemasukan sendiri, tetapi rata-rata pengurus kelompok tani mendapat bagian pemasukan terbesar sekitar 51\%-57\%.Sementara kelompok petani yang menebas, menebang, dan membakar mendapat porsi pemasukan sekitar 2\%-14\%.

Ditambah lagi, sistem kapitalisme, motif kepentingan diri (selfinterest), kebebasan (fredom), dan kompetisi tidak bermoral, dan rezim kapitalisme telah berhasil menjadikan alam sebagai objek eksploitasi dengan bebas.Perubahan sistem ekonomi dengan adanya liberalisasi perdagangan telah disinyalir turut mempercepat kerusakan dan pencemaran di bumi. Dalam perdagangan bebas, pakar ekonomi akan selalu bangga dan optimis terhadap pertumbuhan ekonomi yang tinggi. Dengan ini mengindikasikan adanya peningkatan kapasitas penggunaan sumber daya alam.Peningkatan pengolahan sumber daya alam tentunya dapat memunculkan kerusakan lingkungan. Tentunya keruskan itu kelak akan menjadi sumber bencana alam akibat ulah manusia.

Secara normatif, manusia memiliki potensi melakukan kejahatan. Ketika Allah SWT bermaksud menciptkan makhluk bernama manusia, 
Allah berfirman: "Aku akan menciptakan di muka bumi ini seorang khalifah". Namun, setelah itu muncul sebuah pertanyaan dari para Malaikat, yaitu: "Apakah Engkau menciptakan makhluk yang akan melakukan kerusakan di muka bumi dan mengalirkan darah?" Maka Tuhan pun menjawab: "Sesungguhnya Aku lebih tahu apa yang tidak kamu ketahui” (QS. 2: 30). Ayat ini menunjukkan bahwa manusia memiliki dua potensi kejahatan, yaitu merusak (ifsad) dan mengalirkan darah (isfak ad-dima').

Terkait dengan kerusakan lingkungan, Islam adalah agama konprehensif tentunyadapat menjawab tantangan-tantangan realitas yang ada di dunia hingga masa akhir nanti. Tantangan tersebut dapat berupa tantangan yang berhubungan dengan tauhid, jinayah maupun muamalah. Walaupun tantangan dari kedinamisan perjalanan masa dapat terjawab dengan sempurna oleh Islam, tetapi banyak kalangan tetap berasumsi bahwa jalan terbaik menghilangkan asumsi tersebutharus dijawab secara ilmiah, sehingga pemecahan persoalan terjawab secara obyektif (Rasjidi, 1976:7). Disinilah dibutuhkan spiritualitas dan lingkungan dalam perspektif Islam, karena Islam sebagai agama yang memiliki dimensi spritualitas, sehingga melahirkan keharmonisan manusia dengan lingkungan.

\section{METODE PENELITIAN}

Jenis penelitian ini jika dilihat dari lokasi dan sumber data termasuk kategori penelitian kepustakaan (library research). Hal ini dengan cara mengkaji, menelaah, menganalisa dan meneliti sumber-sumber kepustakaan serta menghimpun bahan-bahan tertulis dalam bentuk kitab, buku, artikel, jurnal, tulisan lepas, opini, makalah-makalah, dan sumbersumber tertulis lainnya yang berkaitan dengan kajian, yaitu: spritualitas dan lingkungan hidup.

Pendekatan yang digunakan dalam penelitian ini adalah kualitatif. Menurut Anselm Strauss dan Julient Corbin (2007: 5), metode kualitatif dapat digunakan untuk mengungkap dan memahami sesuatu di balik fenomena yang belum diungkap sama sekali. karena itu, penelitian ini mendeskripsikan secara induktif tentangspiritualitas dan lingkungan hidup.Adapun sumber data primer adalah sumber data yang secara detail menerangkan mengenai spritualitas dan lingkungan hidup yang 
terdapat dari berbagai referensi berupa al-Qur'an, Hadis nabi, pendapat ulama dan para pakar. Sumber sekunder adalah sumber pendukung sebagai data tidak langsung seperti jurnal, website, majalah, makalah atau sejenisnya yang relevan dengan fokus penelitian. Kemudian datadata tersebut didiskripsikan secara taken for granted (apa adanya) untuk selanjutnya dianalisa.

Sedangkan teknik pengumpulan data dalam penelitian ini adalah dokumentasi. Dokumentasi adalah mengumpulkan, mengklasifikasikan, dan mengolah data sesuai dengan fokus penelitian. Ia adalah pernyataan tertulis yang disusun oleh seseorang atau lembaga untuk keperluan pengujian suatu peristiwa(Moleong: 2009: 216). Penelitian ini menggunakan triangulasi dalam pengumpulan data agar dapat menutupi kekurangan dari satu metode pengumpulan data, sekaligus menyempurnakan data atau informasi yang tidak diperoleh melalui metode lain. Kemudian data itu dianalisis melalui pendekatan kualitatif, dengan langkah-langkah (Iskandar, 2009: 140-143; Moleong, 2009: 228229), yaitu:Pertama, melalui reduksi data sebagai proses pengumpulan data penelitian. Pada tahap ini, peneliti merekam data lapangan dalam bentuk catatan-catatan lapangan (field note), menafsirkan, dan menyeleksi. Kedua, display data atau penyajian data dalam bentuk narasi teks. Data yang tersaji dianalisis, disusun secara sistematis dan simultan untuk menjelaskan dan menjawab pokok permasalahan penelitian. Langkah selanjutnya, ketiga, adalah kesimpulan atau verifikasi, yang merupakan analisis lanjutan dari reduksi dan display data.

\section{PEMBAHASAN}

Dalam Kamus Besar Indonesia secara etimologi,lingkung.an [n] (1) daerah (kawasan dsb) yang termasuk di dalamnya; (2) bagian wilayah dl kelurahan yg merupakan lingkungan kerja pelaksanaan pemerintahan desa; (3) golongan; kalangan: ia berasal dr bangsawan; (4) semua yg mempengaruhi pertumbuhan manusia atau hewan: kita harus mencegah pencemaran . Menurut pasal 1 Undang-undang Nomor 23 Tahun 1997, disebutkan, "Lingkungan adalah kesatuan ruang dengan semua benda, daya, keadaan, dan makhluk hidup, termasuk manusia dan perilakunya, yang mempengaruhi kelangsungan perikehidupan dan 
kesejahteraan serta makhluk hidup lainnya. Berdasarkan definisi ini, cakupan lingkungan hidup terdiri dari beberapa unsur-unsur, yaitu ruang, semua benda, daya atau energi, dan makhluk hidup.

\section{Hubungan Manusia dengan Lingkungan}

Islam merupakan agama yang membawa rahmah pada segala alam. Adapun bentuk rahmah akan terwujud dalam bingkai spiritualitas, dimana agama bukan hanya mengatur masalah yang dahir tetapi juga dalam masalah yang bersifat batin. Mengamalkan Islam secara dahir hanya mengarah pada pemahaman yang dangkal dan tirani, sementara mengamalkan Islam secara batin saja akan melahirkan utupis belaka. Karena itu mengamalkan keduanya secara bersamaan akan melahirkan afektif secara menyeluruh. Disinilah pentingnya spiritualitas sebagai roh ajaran Islam yang dapat menghidupkan nilai-nilai subtansial. Spiritualitas adalah proses pembentukan jiwa yang berbanding lurus antara hati dengan anggota badan secara riil. Tentunya, hubungan manusia dengan makhluk lain adalah setara atau bersifat simboitik (keduanya saling menguntungkan).

Manusia bukanlah makhluk yang berdiri sendiri yang tidak tergantung pada lainnya. Dalam hal ini, manusia memiliki keterkaitan dengan lingkungan, dimana hubungan manusia dengan lingkungan ada empat tahap. Pertama, ekosentrisme adalah manusia merasa bahwa lingkungan sebagai pusat segala-galanya dan manusia merupakan bagian dari lingkungan. Melalui teori ini, lingkungan bukan milik manusia tetapi manusia milik lingkungan (theearth does not belong to man, man belong to the earth). Kedua, transisional adalah manusia tidak merasa bagian dari lingkungan sepenuhnya. Akibatnya, prilaku tanggung jawab, dengan kata lain ingin memeluk gunung tetapi apa daya tangan tak sampai. Ketiga, antroposentris adalah manusia bukan bagian lagi dari lingkungan, tetapi ada di luar lingkungan. Hal ini dapat mengantarkan manusia pada sifat rakus dan menimbulkan kerusakan lingkungan. Keempat, holistik adalah manusia bagian integral dari lingkungan tetapi manusia memiliki akal dan kebebasan ketimbang dengan makhluk lain. Melalui akal dan kebebasan, manusia mampu mengelola dan melestarikan lingkungan yang memiliki aspek hukum. sebagaimana dikatakan oleh Abd al-Wahhab Khallaf(1968: 11), berikut ini: 


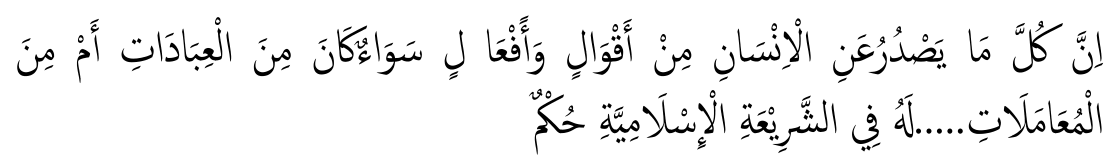

Artinya: "Sesungguhnya setiap perkataan dan perbuatan manusia baik ibadah atau mu'amalat... di dalam syari'at Islam memiliki bukum."

Dalam hal ini, hubungan manusia dengan lingkungan termasuk kategori yang keempat. Ulama terdahulu menyatakan bahwa hubungan manusia dengan makhluk adalah muamalah. Muamalah adalah adanya dua pihak yang saling bekerja yang berkaitan, misalnya adanya ijab dari salah satu dan menerima dari pihak yang lain (al-Bajuri, t. th/I: 338). Ditambah lagi dengan konsep wibdah al-wujud (kesatuan wujud) bahwa hubungan manusia dengan lingkungan adalah sederajat sebab hakikat wujud yang sebenarnya hanyalah Allah SWT, sementara manusia dan alam ini hanya merupakan manifestasi keberandaan Allah SWT. Karena itu, manusia tidak boleh melakukan sewenag-wenang terhadap lingkungan.

Islam adalah agama yang mengajarkan tentang doktrin atau aturan yang dapat mengantarkan manusia menjadi sempurna (al-insan al-kamil). Doktrin ini sangat berpengaruh terhadap makna kehidupan yang dapat dipertanggungjawabkan secara transendental. Secara umum, semua agama memiliki arti penting bagi manusia yang terdiri dari dua konsep dasar bagi kehidupan, yaitu agama dalam arti 'what religion does' dan 'wahat is religion'. Pengertian pertama mengacu pada aspek fungsi agama bagi kehidupan manusia, sedangkan pengertian yang kedua adalah apa makna agama bagi kehidupan manusia (Moesa, 2007: 20). Berkaitan dengan lingkungan hidup, Islam sebagai agama yang terdiri dari elemen esoterisme (batin) dan eksetorisme(dahir) yang memiliki fungsi baik bagi kehidupan manusia maupun makna yang berpengaruh pada manusia. Kedua elemen ini merupakan fungsi dan makna agama bagi kehidupan, yangterdiri dari beberapa prinsip-prinsip yang harus dilakukan oleh manusia terhadap lingkungan, sebagai berikut:

\section{a. Sikap Hormat terhadap Alam (Respect For Nature)}

Kewajiban manusia sebagai khalifahdi bumi adalah menjaga dan mengurus bumi dan segala yang ada di dalamnya untuk dikelola sebagaimana mestinya. Dalam hal ini kekhalifahan sebagai tugas Allah 
untuk mengurus bumi harus dijalankan sesuai dengan dan tujuan penciptanya (Nasution, 1992: 542).

Pengertian khalifah disini adalah bukan mengeploitasi alam tetapi menghormati keberandaannya sehingga menjadi stabil dan ramah, sebagaimana firman Allah (QS. al-Anbiya': 107), "Dan tiadalah kami mengutus kamu, melainkan untuk (menjadi) rahmat bagi semesta alam”.Rahmatan lil alamin merupakan tujuan dari Islam sebagai ruh disyariatkan suatu hukum. Pengelolaan lingkungan sebagai manifestasi dari rasa kasih bagi alam semesta.Disamping Islam melarang membuat kerusakan di muka bumi, manusia juga mempunyai kewajiban untuk menjaga lingkungan dan menghormati alam semesta yang mencakup jagat raya (manusia, tumbuhan, hewan, makhluk hidup lainnya, dan makhluk tidak hidup).

Dalam fiqh terdapat konsep mubtaram yang mengindikasikan adanya penghormatan manusia terhadap lingkungan. Prinsip hormat ini merupakan etis moral yang harus dilakukan manusia sebagai khalifah (legislatif Tuhan) di muka bumi dan secara ontologis manusia adalah bagian integral dari alam, sesuai dengan firman Allah (QS. al-Baqarah: 30), "Ingatlah ketika Tuhanmu berfirman kepada para malaikat: "Sesungguhnya Aku hendak menjadikan seorang khalifah di muka bumi."Konsep khalifah sebagai wakil Tuhan di muka bumi akan terwujud, jika manusia mampu melestarikan bumi ini,sehingga seluruh peribadatan (hubungan vertikal) dan amal sosial (hubungan horizontal) dilakukan sebaik mungkin. Ayat tersebut lebih bersifat antroposentris, tetapi ada perintah untuk mengelolanya harus berdasarkan penuh keseimbangan antara pengembangan dan pelestarian.

Hormat terhadap alam merupakan suatu prinsip dasar bagi manusia sebagai bagian dari integral alam semesta.Setiap komunitas sosial memiliki kewajiban untuk menghargai kehidupan bersama.Bagitu pula setiap anggota komunitas ekologis harus menghormati setiap kehidupan dan spesies dalam komunitas ekologis, serta memiliki kewajiban moral untuk menjaga kohesivitas dan integritas komunitas ekologis, alam tempat hidup manusia.Menurut KH. Ali Yafie (2006: 173-174) dalam fiqh terdapat ketentuan prinsip dasar bahwa semua makhluk mempunyai status hukum mubtaram (bukan dalam arti terhormat) tetapi harus dilindungi eksistensinya, sehingga siapapun dilarang membunuhnya. 
Termasuk melindungi lingkungan adalah tidak mencemarinya yang dapat menimbulkan kerusakan lingkungan.Sebab, pencemaran lingkungan sebenarnya kembali akibatnya terhadap manusia itu sendiri. Nabi SAW bersabda, "Jauhilah dua perbuatan yang mendatangkan laknat!" Sahabat-sahabat bertanya, "Apakah dua perbuatan yang mendatangkan laknat itu?" Nabi SAW menjawab, "Orang yang buang air besar di jalan umum atau di tempat berteduh manusia." begitu pula Nabi SAW bersabda, "Janganlah seorang dari kalian kencing di air tenang yang tidak mengalir kemudian mandi di dalamnya."(HR. Bukhari Muslim).

\section{b. Prinsip Tanggung Jawab terhadap Lingkungan}

Islam berupaya menyadarkan manusia yang beriman agar menginsafi bahwa masalah lingkungan hidup tidak lepas dari tanggung jawab manusia yang beriman dan merupakan amanat yang diembannya untuk memelihara dan melindungi alam yang dikaruniakan oleh Allah SWT. Modal utama adalah etis moral untuk mendukung segala upaya untuk mengatasi kerusakan lingkungan hidup sebagai bentuk rasa tanggungjwab manusia.

Sikap bertanggung jawab tersebut harus dikembangkan demi lestarinya lingkungan dan pembangunan disegala aspek kehidupan manusia yang berkelanjutan (sustainable development). Oleh karena itulah perlu didukung oleh segala komponen masyarakat agar alam ini tetap terpelihara dan permanen. Diantara komponen masyarakat adalah pemerintah (umara'), cerdik pandai (ulama'), mediator,pengusaha dan rakyat secara keseluruhan. Konsekuensinya, masing-masing komponen tersebut harus bergotong-royong dalam melestarikan daya dukung lingkungan demi masa depan generasi berikutnya (Amin, 1995: 200). Dalam Islam tidak dibenarkan mengembangkan alam bersifat temporal dan dinkmati oleh waktu tertentu saja tetapi harus berkelanjutan hingga generasi berikutnya. Menghabiskan sumber daya alam adalah bertentangan dengan prinsip-prinsip universal ajaran Islam (al-mabadi' al-'ammah) yang pada akhirnya akan menimbulkan kemusnahan alam, sebagaimana yang terjadi di negeri Nouru.

Kerusakan alam bukan dari faktor alam tetapi akibat dari keserakahan manusia yang tidak mempertimbangkan kemaslahatan, bahkan mereka 
mengatasnamakan pembangun yang berasal dari kepentingan pribadi dan kapitalis global, sebagaimana Allâh SWT berfirman:

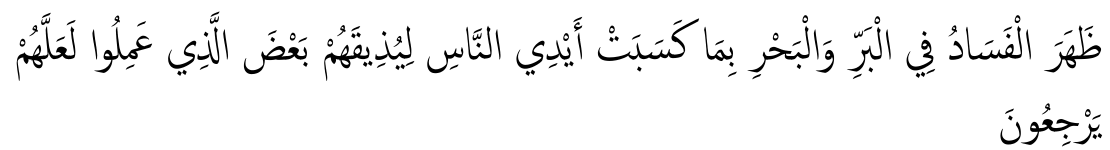

Artinya "Telab nampak kerusakan di darat dan di laut disebabkan karena perbuatan tangan manusi, supaya Allâb merasakan kepada mereka sebahagian dari (akibat) perbuatan mereka, agar mereka kembali (ke jalan yang benar) [ar-Rûm/30:41].

Ibnu Katsîr (t. th) mengutip pendapat Zaid ibn Râfi' bahwa yang dimaksud "telah nampak kerusakan" adalah hujan tidak turun di daratan sehingga mengakibatkan krisis kelaparan dan di lautan yang menimpa binatang-binatang." Memang sejak awal manusia pertama (Adam dan istrinya) telah diperintahkan oleh Allah SWT untuk menjaga kelestarian surga. Oleh karena itu, dalam situasi dan kondisi dimana kerusakan alam sudah parah dan keserakan manusia untuk mengekspolitasi alam, maka Islam secara preventif melarangnya. Segala sesuatu yang boleh tetapi mengantarkan kepada kemudaratan adalah haram hukumnya.

Tanggung jawab manusia terhadap lingkungan merupakan pelestarian lingkungan secara dinamis dan humanis.Dalam Islam ada tiga macam bentuk pelestarian lingkungan. Pertama, dengan cara ibya'. Yakni pemanfaatan lahan yang dilakukan oleh individu. Dalam hal ini seseorang mematok lahan untuk dapat digarap dan difungsikan untuk kepentingan pribadinya. Orang yang telah melakukannya dapat memiliki tanah tersebut. Mazhab Syafi' imenyatakan siapapun berhak mengambil manfaat atau memilikinya, meskipun tidak mendapat izin dari pemerintah. Abu Hanifahberpendapat, Ihya' boleh dilakukan dengan harus mendapat izin dari pemerintah yang sah. Imam Malik juga berpendapat hampir sama dengan Imam Abu Hanifah. Akan tetapi, beliau menengahi dua pendapat itu dengan cara membedakan dari letak daerahnya.Kedua, dengan proses iqta'. Yakni pemerintah memberi jatah pada orang-orang tertentu untuk menempati dan memanfaatkan sebuah lahan. Adakalanya untuk dimiliki atau hanya untuk dimanfaatkan dalam jangka waktu tertentu. Ketiga, adalah dengan cara hima. Dalam hal ini pemerintah menetapkan suatu area untuk dijadikan sebagai kawasan lindung yang difungsikan untuk kemaslahatan 
umum. Dalam konteks dulu, hima difungsikan untuk tempat penggembalaan kuda-kuda milik negara, hewan, zakat dan lainnya. Setelah pemerintah menentukan sebuah lahan sebagai hima, maka lahan tersebut menjadi milik negara. Tidak seorang pun dibenarkan memanfaatkannya untuk kepentingan pribadinya (melakukan ibya'), apalagi sampai merusaknya (Yafie, 2006). Ketiga bentuk pelestarian tersebut harus diposisikan secara berkesinambungan secara moderat, sehingga melahirkan keadilan sosial.

Dalam bentuk tanggungjwab terhadap lingkungan, perlu adanya rumusan rukun iman pembangunan, sehingga manusia tidak keluar dari nilai-nilai transendetal dan koridor agama. Selama ini, pembangunan bersifat paradoks, dimana seakan-akan keimanan tidak berkaitan dengan pembangunan sama sekali, padahal seharusnya agama yang bersifat sakral harus dipersandingkan dengan pembangunan yang bersifat profan, sehingga tidak melahirkan sekulerisme. Mujiono Abdillah merumuskan iman pembangunan menjadi tiga, yaitu: pertama, pembangun merupakan keniscayaan untuk mengoptimalkan daya dukung lingkungan bagi kehidupan. Kedua, manusia merupakan makhluk pembangunan yang berkualitasnya ditentukan oleh pembangunan. Ketiga, hakikat pembangunan adalah pembangunan yang holistik dan integralistik (Abdillah, 2001: 66). Akibatnya keimanan seseorang berbanding lurus dengan tanggung jawab terhadap lingkungan. Yakni, tidaklah dikatakan seseorang beriman yang sejati merusak lingkungan. Salah satu prinsip untuk memperoleh umur panjang dan penuh berkah adalah tidak memotong pohon yang basah kecuali ada tujuan, sebagaimana perkataan Syech az-Zarnuji (t. th: 48):

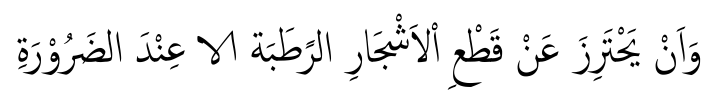

Artinya: "Seharusnbya seseorang menjahui dari memotong pobon-pobon yang hijau kecuali ada kebutuban."

\section{c. Prinsip Kepedulian terhadap Lingkungan (Caring For Nature)}

Prinsip kepedulian terhadap lingkungan ada dua macam, yaitu kepedulian secara pasif (passive caring) dan kepedulian secara aktif (active caring). Kepedulian secara pasif, Islam menganggap bahwa menjaga 
lingkungan termasuk bagian dari iman. Dalam kitab klasik banyak dijelaskan tentang kesalehan lingkungan, di antaranya perkataan Nabi bahwa membuang duri di jalan termasuk bagian dari iman, al-Ghazali diampuni dosanya karena membiarkan lalat minum tintanya, wanita masuk neraka karena mengikat kucing, wanita diampuni dosanya karena menolong anjing kehausan, dan larangan membakar semut. Abu Yazid alBustami membiarkan semut di bajunya selama beberapa hari. Maka logis, ulama sepakat bahwa bagi orang yang melakukan ihram dalam ibadah haji dan umrah diharamkan memburu binatang dan menggangunya (ad-Dimasyqi, t. th/I: 230). Ibadah haji merupakan prosesi ritual yang melambangkan dimensi kepedulian terhadap lingkungan hidup.

Begitu pula termasuk kepedulian pasif adalah Islam mewajibkan umat Islam agar dalam memanfaatkan sumber daya alam tidak berlebihan (israf), tidak boros (tabdzir), tidak berfoya-foya, tidak merusak habitat atau keseimbangan alam, dan membuat polusi. Sebaliknya, Islam mengedepankan asas harmoni, keseimbangan, dan kelestarian, melindungi dan memperbaiki yang terancam rusak, punah, atau sudah rusak; dan menggiatkan penghijauan. Pada prinsipnya, menanam adalah lebih baik daripada memetik tanpa ikut menanam, sebagaimana perkataan orang bijak, "la qad gharasu hatta akalna wa innana la naghras hatta ya'kul an-nass ba'dana" (Sungguh telah menanan orang yang terdahulu, sehingga kami dapat memakan buahnya dan sesungguhnya kami sedang menanam agar orang-orang sesudah kami dapat memetik buahnya). Dalam hal ini, orang sekarang ini tidak boleh menghabiskan sumber daya alam ini, karena generasi selanjutnya akan mengalami kehabisan sumber alam. Buku "The Quality of Growth" dari Wold Book 2000 menyajikan hasil penelitian yang berkaitan dengan degradasi lingkungan. Diantaranya polusi udara mengakibatkan kerusakan pernafasan, penyakit jantung, paru-paru, dan kangker yang pada akhirnya menyebabkan hilangnya jiwa manusia.

Sementara kepedulian secara aktif adalah menjaga lingkungandengan reboisasi (penghijauan kembali hutan yang telah tebang). Disinilah kewajiban pemerintah mewajibkan kepada rakyatnya untuk melakukan penghijauan kembali. Menurut al-Qurthubi (t. th/III: 306), bercocok tanam termasuk fardhu kifâyah (kewajiban sosial). Penguasa berkewajiban mendesak rakyatnya untuk bercocok tanam dan menanam pohon. Pendapat ini senada dengan hadis Nabi SAW: "Muslim manapun saja yang 
menanam sebuah pohon lalu ada orang atau hewan yang memakannya, maka baginya dicatat sebagai pahala sedekah (HR. Al-Bukhâri, No. 6012). Dengan demikian, sedekah dalam Islam bukan hanya bersifat horizontal saja (sedekah humanistik), tetapi berkaitan pula dengan sedekah terhadap lingkungan hidup (sedekah ekologis).

Menurut Ali Yafie (2006), ada dua landasan dasar dalam fiqh al-bi'ah. Pertama, pelestarian dan pengamanan lingkungan hidup dari kerusakannya adalah bagian dari iman. Kualitas iman seseorang bisa diukur salah satunya dari sejauh mana sensitivitas dan kepedulian orang tersebut terhadap kelangsungan lingkungan hidup. Kedua, melestarikan dan melindungi lingkungan hidup adalah kewajiban setiap orang yang berakal dan baligh (dewasa). Melakukannya adalah ibadah, terhitung sebagai bentuk bakti manusia kepada Tuhan. Sementara penanggung jawab utama menjalankan kewajiban pemeliharaan dan pencegahan kerusakan lingkungan hidup ini terletak di pundak pemerintah. Ia telah diamanati memegang kekuasaan untuk memelihara dan melindungi lingkungan hidup, bukan sebaliknya mengeksploitasi dan merusaknya.

Di sekeliling manusia ada makhluk lain yang menggantungkan hidup pada bumi, air, dan udara. Akibatnya, manusia tidak boleh merusak lingkungan mereka, karena mereka juga membutuhkan air dan udara yang bersih. Manusia dalam mengelola alam harus menjaga kelestarian lingkungan sesuai dengan misi Islam rabmatal lil 'alamin. 'Alamin. Lingkungan disini memiliki arti yang sangat luas yang meliputi benda biotik (benda hidup) dan abiotik (benda mati). Bukti kepedulian lingkungan, seperti al-Ghazali setelah meninggal dunia ada seseorang yang bermimpi dirinya bahwa segala amal kebaikannya tidak diterima oleh Allah, tetapi karena ia pernah membiarkan lalat minum tintanya, maka akhirnya dosanya diampuni oleh Allah SWT sebagai bentuk belas kasih terhadap makhluk (an-Nawawi, t. th: 86).

Sedangkan kerusakan lingkungan adalah akibat kerakusan manusia yang mengeksploitasi sumber-sumber alam tanpa mempertimbangkan kemaslahatan. Konsekuensinya, sulit sekali tercapai "zero environmental impact" (Tidak ada dampak lingkungan). Islam sebagai agama berdimensi spritualitas yang tinggi menjaga keseimbangan antara peningkatan ekonomi dengan kelestarian lingkungan. Artinya, sekalipun untuk kepentingan ekonomi sangat potensial tetapi akan berimpilkasi tejadinya 
kerusakan lingkungan yang luas, maka dilarang atau haram hukumnya, sebagaimana kaidah ushul fiqh, "Mengabaikan kemudaratan yang bersifat khusus untuk menolak kemudaratan yang bersifat umum" (Khallaf, 1968: 207).

Dalam Islam, kepedulian terhadap makhluk termasuk nilai ibadah dan penebus dosa bagi manusia. Jika ada seseorang yang merusaknya, maka ia akan memperoleh siksa dari Allah SWT, sebaliknya jika seseorang peduli terhadap lingkungan, maka ia kan memperoleh belas kasihNya. Nabi SAW bersabda: "Duhulu ada seekor anjing yang hampir mati karena kehausan mengelilingi sebuah sumur. Tiba-tiba seorang wanita pelacur Bani Israil melihat anjing, kemudian pelacur itu melepaskan sepatunya untuk mengambil air dengan sepatunya lalu memberi minum anjing tersebut, maka wanitapelacur tersebut diampuni dosanya (Muttafaq 'alaib)." Sebaliknya berbuat menyakiti terhadap makhluk termasuk perbuatan dosa yang akan memdapatkan sikasa dari Allah SWT, sebagaimana keterangan Nabi SAW, "Dari Abdullah ibn Umar bahwa Nabi SAW bersabda, "Seorang wanita disiksa karena seekor kucing, dimana ia mengurung kucing hingga mati, maka wanita tersebut masuk neraka. Dia tidak memberi kucing itu makan dan minum, karena dia mengurungnya sehingga tidak dapat memakan serangga tanah."

Dalam konteks ini, tidak peduli terhadap lingkungan adalah perbuatan keji dan berdosa.Dosa manusia terdiri dari tiga macam, yaitu dosa kepada Allah SWT, dosa kepada sesama manusia, dan dosa kepada lingkungan.Untuk keluar dari dosa, maka dibutuhkan minta ampun (taubat).Taubat kepda Allah cukup dengan penyesalan yang mendalam, sementara taubat kepada sesama manusia adalah disamping bertaubat kepada Allah juga harus minta maaf kepada yang bersangkutan. Adapun taubat kepada lingkung dan bagaimana cara taubatnya, dalam hal ini ulama tidak dapat merumuskan taubat model yang terakhir ini. Ibn Umar an-Nawawi (t. th: 85-86), ulama Nusantara menyatakan bahwa apabila dosa berkaitan dengan hewan (lingkungan) termasuk masalah yang sulit sekali, seperti memukulnya tanpa ada alasan yang benar, memukul di mukanya, memberi beban di atas kemampuannya, dan tidak memberi makan dan minum.Dengan demikian, kepedulian terhadap lingkungan merupakan kewajiban agama yang harus dilakukan oleh setiap manusia di muka bumi ini. 


\section{Hukuman Bagi Perusak Lingkungan}

Pengrusakan lingkungan adalah salah satu bentuk pelanggran atau bentuk melampauan batas, sebagaimana firman Allah SWT, "dan janganlah kamu membuat kerusakan di muka bumi, sesudah perbaikannya yang dilakukan kamu oleh Allah SWT dan atau siapapun dan berdoalah serta beribadab kepada-Nya dalam keadaan takut sehingga kamu lebib mentataatiNya dalam keadaan penub harapan dan anugrah-Nya, termasuk pengabulan do'a kamu" (QS. al-'Araf: 56).

Fakhr ad-Dinar-Razi dalam menafsiri ayat tersebut bahwa dalil larangan membuat kerusakan.Setiap perbuatan yang menimbulkan madharat dilarang agama.Al-Qurtubi menyatakan bahwa penebangan pohon merupakan tindakan pengrusakan yang mengakibatkan adanya kerusakan. Bagitu pula mencemari air termasuk kategori pengrusakan (ar-Razi, t. th/IV: 108-109; al-Qurthubi, t. th/VII: 226). Menurut kajian Ushul fiqh, ketika kita dilarang melakukan sesuatu berarti kita diperintahkan untuk melakuakan kebalikannya (as-Subki, t. th/I: 390). Misalnya, kita dilarang merusak alam berarti kita diperintahkan untuk melestarikan alam.Adapun status perintah tersebut tergantung status larangannya.Secara implisit, larangan merusak alam adalah haram berarti menunjukkan bahwaperintah melestarikan alam adalah wajib pula.

Fatwa MUI tentang Pengelolaan Sumber Daya Alam (Fatwa Islamic Council on Natural Resouces Management), fatwa MUI Wilayah IV Kalimantan tentang Pembakaran Hutan dan Kabut Asap (Edicts of Indonesia Islamic Council on Forest Fire and Haze) dan fatwa Penebangan Liar dan Pertambangan Tanpa Izin lllegal Logging dan Illegal Mining (Edict on Illegal Logging and Illegal Mining). Dalam fatwa MUI tersebut memutuskan dan menetapkan bahwa pembakaran hutan dan lahan untuk kegiatan kehutanan, pertanian, perkebunan, peternakan dan sebagainya yang mengakibatkan kabut asap, kerusakan lingkungan, dan mengganggu kehidupan manusia, maka hukumnya adalah haram (Anonymous, 2007).

Secara psikologi, orang yang melakukan kerusakan pada lingkungan sebenarnya telah diberi sanksi yang abstrak berupa merasa ketenangan alam terhadap kematian perusak lingkungan. Nabi SAW bersabda, "Sesungguhnya apabila seorang yang jahat mati, niscaya para hamba, kota-kota, pepohonan dan binatang-binatang melata merasakan ketenangan” (HR. Bukhâri). Disamping itu, perusakan lingkungan 
sebenarnya akan kembali kepada manusia itu sendiri sebagai khalifah di muka bumi ini. Contoh klasik, Hajar Aswad menjadi hitam karena manusia melakukan kerusakan lingkungan sekaligus berdosa kepada Allah SWT, sebagaimana sabda Nabi SAW, "Hajar Aswad turun dari surga lebih putih warnanya daripada salju, lalu menjadi hitam karena dosa-dosa anak Adam (at-Tirmidzi, t. th/I: 66).

Melalui pendekatan maqasid syari'ah, menjaga lingkungan terdiri dari dua. Pertama, aspek menjaga dari kerusakan. Kedua, aspek mengembangkan. Yusuf al-Qardhawi (2010) dalam kitabnya "Ri'ayah al-Bi'ah fi Syari'ab al-Islam" memasukkan pemeliharaan lingkungan (bifdz al-'alam) pada maqashid asy-syari'ah. Hifdz al-'alam yang diproyeksikan sebagai maqashid al-syari'ah adalah untuk menjaga kekayaan alam, menjaga dan mengelola sumber-sumbernya, dan menjaga kelestariannya. Setiap tindakan yang bertentangan dengan bifdz al-'alam adalahsama dengan menghilangkan maqashid asy-syari'ah. Karena itu, orang yang merusak tatanan ekosistem (nidham al-bi'ab) termasuk cakupan dalam keumuman ayat, "Orang-orang yang memerangi Allah dan Rasul-Nya” (QS. al-Maidah: 33). Pada umumnya, ulama fiqh mengkaji quththa' ath-thariq berdasarkan ayat ini. Dalam hal ini, perusakan terhadap lingkungan dinamakan birabah al-bi'ab (perampokan lingkungan) dan pelakunya harus dihukum seberat-beratnya, sebagaimana hukuman bagi quththa' ath-thariq atau birabah.

Namun demikian, jika merusak lingkungan termasuk kategori kejahatan yang tidak ada dasarnya dalam agama ( $h a d$ ), maka dapat dikategorikan sebagai ta'zir. Dalam Islam,apabila sebuah tindakan kejahatan tidak ada nash hukumannya dalam syariat, maka pelaku tindakan kriminal mendapatkan hukuman berupata'zir. Ta'zir adalah hukuman yang dimaksudkan untuk mendidik ( $a^{\prime} d^{\prime} i b$ ) atas suatu perbuatan maksiat yang tidak disyariatkan (Audah, t. th/I: 685). Sanksi yang berbentuk ta'zir diserahkan sepenuhnya kepada pemerintah sesuai dengan besar kecilnya dampak kejahatan yang dilakukan. Hal ini sebagaimana dinyatakan dalam kaidah fiqh:

Artinya: "Hukuman ta'zir diserahkan kepada pemerintah sesuai dengan kadar besar kecilnya kejahatan."

Memang Islam tidak menentukan hukuman tertentu untuk kejahatan ta'zir. Karena itu, sangat logis jika menentukan hukuman ta'zir diserahkan 
kepada pemerintah (Audah, t. th/I: 685).Pada prinsipnya, hukuman ta'zir tidak sampai membinasakan pelaku, tetapi mayoritas ulama fiqh memperbolehkan ta'zir dengan hukuman mati apabila kemaslahatan menghendakinya, atau jika kejahatan pelaku tidak dapat hilang melainkan dengan hukum mati. Dalam hal ini, jelas hukuman mati bagi perusak lingkungan harus ditegakkan sebagai tujuan hukum, bahkan melebihi efek negatifnya dibandingkan dengan narkoba. Hukuman mati bagi perusak lingkungan akan memberi kontrol yang sangat strategis untuk kelestarian lingkungan.Menurut Geny, tujuan hukum adalah untuk mencapai keadilan. Tujuan hukum ditentukan oleh unsur keyakinan seseorang yang dinilai etis. Adil atau tidak, benar atau salah.Yang menjadi tumpuan dari teori ini, hukum berada pada tiap-tiap batin orang yang menjadi ukuran untuk menentukan keadilan dan kebenaran.Sementara menurut Sutjipto Rahardjo, tujuan hukum adalah membimbing manusia pada kehidupan yang baik, aman, tenteram, adil, damai dan penuh kasih sayang.

\section{PENUTUP}

Islam merupakan agama konprehensif tidak hanya mengatur masalah ibadah saja tetapi meliputi segala aspek kehidupan, terutama spiritualitas. Islam memiliki arti penting bagi manusia yang terdiri dari dua konsep dasar, yaitu agama dalam arti what religion does (fungsi agama dalam kehidupan) dan wahat is religion (makna agama bagi kehidupan). Kedua arti tersebut sangat berkaitan dengan hubungan manusia dengan lingkungan, dimana hubungan keduanya bersifat setara atau simbiotik, yaitu saling menguntungkan antara manusia dengan lingkungan. Sebagai bentuk perwujudan dari rabmatal lil 'alamin, manusia harus memiliki prinsip-prinsip terhadap lingkungan. Pertama, prinsip sikap hormat terhadap alam. Kedua, prinsip tanggung jawab terhadap lingkungan. Ketiga, prinsip kepedulian terhadap lingkungan. Ketiga prinsip tersebut tidak akan efektif, maka dibutuhkan kontrol dari pihak penguasa berupa hukuman yang seberatnya hingga hukuman mati. 


\section{DAFTAR PUSTAKA}

Abdillah, Mujiono, 2001, Agama Rabmah Lingkungan Perspektif al-Qur'an, Jakarta: Paramadina.

Ad-Dimsyiqi, al-Hishni al-Husaini, t. th, Kifayah al-Abyar fi Hill Ghayah al-Ikhtishar, t. p: Pesantren.

Al-Bajuri, t. th, Hasyiyah al-Bajuri 'ala ibn Qasim al-Ghazi, Semarang: Thoha Putra.

Al-Bukhari, t. th, Shabih al-Bukhari,Beirut: Dar al-Fikr.

Al-Qardhawi, Yusuf, 2002, Islam Agama Ramah Lingkungan. Abdullah Hakam Shah, dkk. (terj.), Jakarta: Pustaka Al-Kautsar.

Al-Qurthubi, t. th,at-Tafsir li Abkam al-Qur'an, Beirut: Dar al-Fikr.

Amin, Masyhur, 1995, Dinamika Islam Sejarab Transformasi dan Kebangkitan, Yogyakarta: PKPSM.

An-Nawawi, ibnu Umar, t. th, Marqah Shu'ud at-Tashdiq fi Syarb Sullam at-Taufiq, Surabaya: Syirkah Bungkul Indah.

Anonymous, 2007, Ulama Internasional Membahas Lingkungan Dalam Perspektif Islam, Bogor:Fakultas Kehutanan IPB.

Ar-Razi, t. th, al-Tafsir al-Kabir, Beirut: Dar al-Fikr.

As-Subki, t. th, Syarb Matn al-Jam'u al-Jawami', Beirut: Dar al-Fikr.

Ati-Tirmidzi, t. th, Sunan Abi Daud at-Tirmidzi,Beirut: Dar al-Ma'rifah.

Audah, Abd al-Qadir, t. th, at-Tasyri' al-Jinai fi al-Islam, Beirut: Mu'assasah ar-Risalah.

Az-Zarnuji, t. th, Ta'lim al-Muta'allim, Surabaya: Nur al-Huda.

Departemen Pendidikan Nasional, 2002, Kamus Besar Bahasa Indonesia, Jakarta: Balai Pustaka.

Ibn Katsir, t. th, Tafsir al-Qur'an al-'Adhim, Beirut: Dar al-Fikr.

Iskandar, 2009, Metode Penelitian Kualitatif: Aplikasi untuk Penelitian Pendididan, Hukum, Ekonomi E Manajemen, Sosial, Humaniora, Politik, Agama dan Filsafat, Jakarta: Gaung Persada (GP Press). 
Khallaf, Abd al-Wahhab, 1968, Ilm Ushul al-Fiqh, Kuwait: Dar al-Qalam.

Moesa, Ali Maschan, 2007, Nasionalisme Kiai: Konstruksi Sosial Berbasis Agama, Yogyakarta: LKiS.

Moleong, Lexy J., 2004, Metode Penelitian Kualitatif, Bandung: PT. Remaja Rosdakarya.

Muhadjir, Noeng,1996,Metodologi Penelitian Kualitatif, Yogyakarta: Rake Sarasin.

Nasution, Harun, 1992, Ensiklopedi Islam Indonesia Jakarta: Djambatan.

Rasjidi, M, 1976, Hukum Islam dan Pelaksanaannya dalam sejarah, Jakarta: Bulan Bintang.

Strauss, Anselm dan Juliet Corbin, 2007, Basic of Qualitative Research, Terj. Muhammad Shodiq dan Imam Muttaqin, Yogyakarta: Pustaka Pelajar.

Yafie, KH. Ali, 2006, Merintis Fiqh Lingkungan Hidup, Jakarta: Yayasan Amanah. 